\title{
Restructuring Teacher Education in the United States: Finding the Tipping Point
}

\author{
By Barbara L. Bales*
}

In the United States, as public demands for quality teachers have escalated, there has been a corresponding increase in national policy efforts to tie the standards of student success to teacher preparation, licensing, and evaluation. This conceptual paper examines how national authorities used specific policy tools to usurp the state's responsibility to ensure quality teaching practices in local schools. A discussion of policy problems and instruments grounds the analysis of teacher education policy activity since 1992. The "tipping point" theory is used to understand how this change in authority. Recommendations for future teacher education research and policy-making are shared.

Keywords: local control, policy instruments, teacher education policy

\section{Introduction}

In the United States, the phrase "local control" is central to rhetorical debates surrounding education reform efforts, including teacher preparation. As public demands for quality teachers have escalated, there has been a corresponding increase in national policy efforts to tie the standards of student success expected at each grade level to teacher effectiveness. The theory of action in these policies is to elevate student achievement levels, particularly for learners historically underserved by local public schools (e.g. Fuhrman 2001; Hamilton, Stecher, \& Yuan, 2008; U.S. Department of Education, 2013). In fact, these policies replace the notion of "local" with a "de facto national curriculum" (Porter, Polikoff, \& Smithson, 2009) delivered by teachers, who have passed nationally-determined performance assessments. Policy-makers around the world must wonder, how the scales of authority over statecontrolled teacher education "tipped" to one of national oversight in the United States.

The policy environment governing the preparation, certification, and licensing of today's educators in the United States is unlike any other in history (Bales, 2006; Borrowman, 1965; Porter, McMaken, Hwant, \& Yang, 2011). In just two decades, through the authorization and reauthorization of key national education policies and their associated funding streams, the United States' education system changed from one based on inputs to one based on outcomes and standards of performance (e.g., Cochran-Smith \& Fries, 2008; Datnow \& Park, 2009; or Hamilton, Stecher, \& Yuan, 2008). Today, all fifty states have

\footnotetext{
${ }^{*}$ Associate Professor, University of Wisconsin - Milwaukee, USA.
} 
adopted a sequence of standards-based reform policies addressing teacher preparation, licensing, and evaluation that tighten links between what teachers know and are able to do with pupil learning. The State of Wisconsin serves as example to illustrate this sequence of national policy changes.

\section{Policy Changes across the Learning to Teach Professional Sequence}

\section{Standards-based Policies in Pre- service Education}

Like most states, learning-to-teach in Wisconsin is a sequence of performance-based activities to support the development of professional teachers. Traditionally, it begins when students first enter a university College of Letters and Science to start their disciplinary-based coursework in Science, Mathematics, History, and English/Language Arts, or the Performing Arts. Then they apply to a School or College of Education to begin their professional program. Admission criteria include a minimum grade point average and students' Praxis I Pre-Professional Skills Tests (PPST) scores; scores that measure basic skills in reading, writing and mathematics. Upon admission, faculty provide coursework in pedagogy and pedagogical content knowledge. More often than not, these courses have an associated clinical or school experience.

\section{Standards-based Policies for Teacher Certification and Licensure}

Before completing their professional program, teacher candidates must take and pass the Praxis II Subject Assessment, which measures a candidate's knowledge of "specific subjects that $\mathrm{K}-12$ educators will teach, as well as general and subject-specific teaching skills and knowledge" (Educational Testing Service, n.d.). Candidates must also produce a portfolio of evidence demonstrating their ability to perform the knowledge, skills, and dispositions highlighted in the 2013 InTASC Model Core Teaching Standards. These ten standards "describe the increasing complexity and sophistication of teaching practice... across three developmental levels" (Council of Chief State School Officers, 2013).

Twenty states require candidates demonstrate this evidence using a Teacher Performance Assessment called the edTPA. The edTPA is designed to give teacher preparation programs access to a multiple-measure assessment system aligned to state and national standards that can guide the development of curriculum and practice around the common goal of making sure new teachers are able to teach each student effectively and improve student achievement (American Association of Colleges for Teacher Education \& Stanford Center for Assessment, Learning \& Equity, n.d.).

Today, all 50 states "have standards that prospective teachers must meet in order to attain an initial teacher license" (U.S. Department of Education-Office of Postsecondary Education, 2013, p. 31). In the State of Wisconsin, teacher 
candidates must also pass the Foundations of Reading Test, a test that "assesses proficiency in and depth of understanding of reading and writing development" (National Evaluation Series-Wisconsin Foundations of Reading, 2014). Students, who successfully complete these four, standards-based assessments, can apply for a five year, non-renewable Initial Educator license issued by the State of Wisconsin.

\section{Standards-based Policies for Teacher Relicensing}

Upon employment, Initial Educators must develop, implement, and complete a Professional Development Plan (PDP) to advance to Professional Educator licensure stage. The PDP must contain a professional goal linked to two or more InTASC Teaching Standards. It must also detail an appropriate series of collaborative, professional activities over a five-year period to help them meet the desired goal. A three-member team comprised of a peer, an administrator, and an Institution of Higher Education representative must approve the PDP Goal. As they move through the PDP process, Initial Educators must collect and submit three to five, interrelated, pieces of evidence documenting both their professional growth and its effect on pupil learning. Once the PDP is verified, the Initial Educator can apply to the State of Wisconsin for a five-year Professional Educator license. This five-year cycle repeats itself framing the continuous improvement of a teacher's professional practice.

\section{Standards-based Policies to Measure Teacher and Principal Effectiveness}

In 2014-15, new teacher and principal evaluation policies were implemented. The Wisconsin Educator Effectiveness (EE) System draws 50\% of its measures from the standards of effective practice defined by the associated professional group while the other $50 \%$ is derived from student learning measures. Data addressing student learning measures may include:

- Individual value-added data on statewide standardized assessments (currently grades 3-7 reading and math);

- District-adopted standardized assessment results;

- Student Learning Objectives (SLOs) established by teachers that draw from teacher-developed or other classroom assessments;

- District choice of data based on improvement strategies and aligned to school and district goals based on areas of need highlighted by the state accountability system;

- For elementary and middle school levels, school-wide reading scores will be used. For high schools, graduation rate will be used (State of Wisconsin Department of Public Instruction, 2011, p. 6).

Building administrators are trained in the new EE system to improve 
reliability in the scores.

\section{Standards-based Policies for Student Learning}

In 2010, the State of Wisconsin adopted the Common Core State Standards for Mathematics and English Language Arts. The Common Core State Standards (CCSS) focus on core conceptual understandings and procedures and communicate what is expected of students at each grade level (Common Core State Standards Initiative, 2015). Adoption, however, created curricular and instructional confusion in the state's schools. This occurred, in part, because "adoption of the Common Core standards... represent[ed] considerable change, especially at specific grade levels but even across ranges of grade levels, ignoring grade-to-grade differences" (Porter, et.al., 2011, p. 114). For now, the CCSS direct attention to the teaching and learning of mathematics and English language arts. Teachers of science and social studies must wait for state adoption of the Next Generation Science Standards (Achieve Incorporated, n.d.) and the Council of Chief State School Officers' Social Studies Assessment, Curriculum and Instruction (SSACI) guidelines (available at (Council of Chief State School Officers, n.d.-b). The Smarter Balanced Assessment System Consortium (Smarter Balanced Assessment Consortium, n.d.) and Partnership for Assessment of Readiness for College and Careers (Partnership for Assessment of Readiness for College and Careers (PARCC), 2015) are currently developing an assessment system aligned to the CCSS.

Standards-based reform policies now permeate the Learning to Teach Professional Sequence from preparation through certification, relicensing, and evaluation in the State of Wisconsin. Across the United States, teacher education programs in most states now operate under a similar alignment of standards, assessments, and accountability policies (U.S. Department of Education-Office of Postsecondary Education, 2013). Figure 1 illustrates the infusion of these standards-based policies across the Learning-to-Teach Professional Sequence. The question remains, why was teacher education constructed as a policy problem and what legislative tools did national authorities use to restructure the learning to teach across the professional sequence? 
Figure 1. Teacher Education Policy Changes in the Learning to Teach Professional Sequence

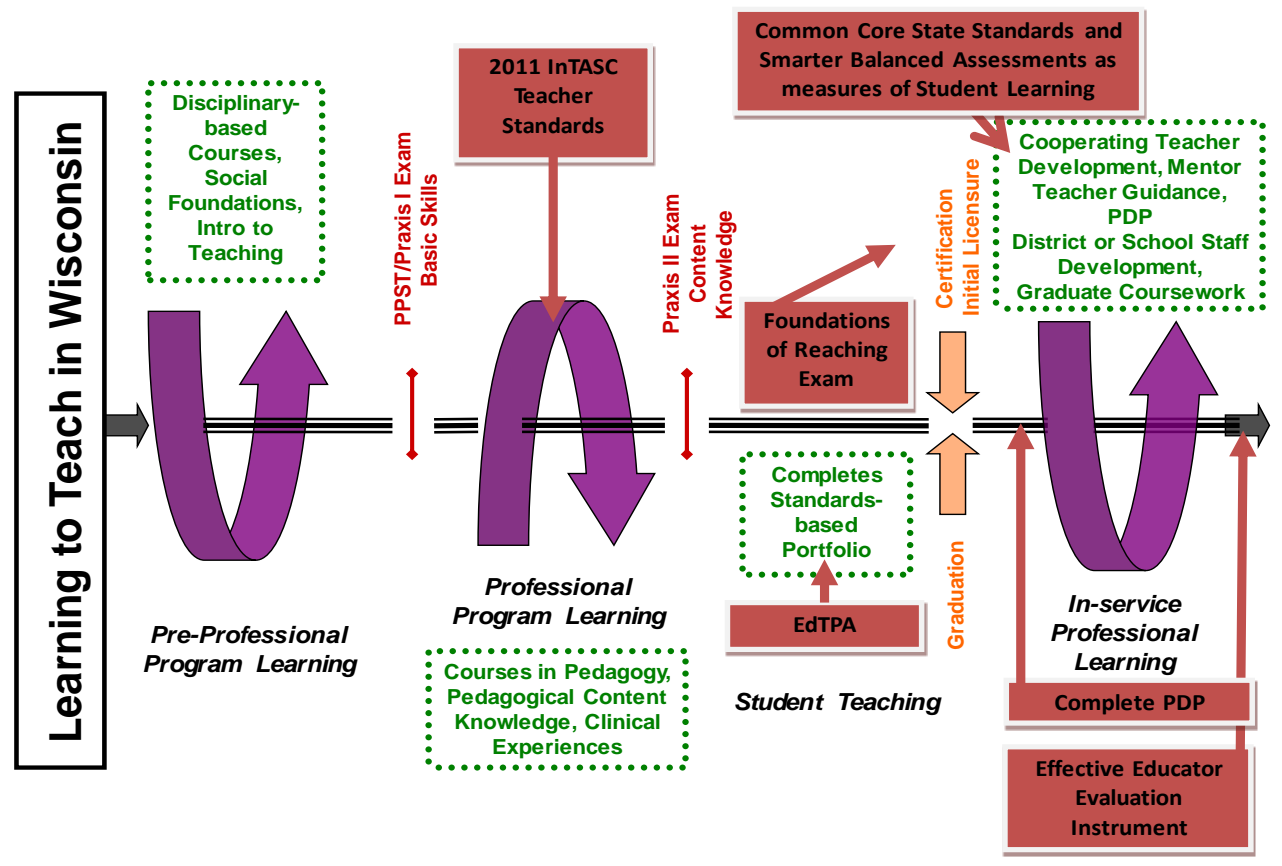

Source: Adapted by author from Bales, 2008

\section{Theoretical Tools for Policy Analysis}

\section{The Theoretical Nature of Policy Problems and Legislative Instruments}

A change in policies often rests on the assumption that there is a problem. While the nature of that problem is "constituted by the differences among its definitions" (Edelman, 1988, p. 15), it often embodies a core set of agreed upon facts generally supported by analytic data. At the core of this particular policy problem is the assumption that teacher quality contributes to student achievement and some authority ought to be accountable for assuring a level of quality. Additionally, every policy carries embedded assumptions about the inherent issue (e.g., Argyris \& Schon, 1974; Majone, 1989). A policy also reflects the normative aspects of a policy-maker's values and the social systems in which both are situated. Policymakers' principles influence which legislative instrument is selected and, at the same time, project an expected outcome.

Policy instruments, or tools, are "mechanisms that translate substantive policy goals into concrete actions" (McDonnell \& Elmore, 1987, p. 134). The array of tools includes mandates, inducements, capacity building, system changing, and ideas. Each has a primary element, an expected result, and a range of associated costs and benefits. Selection of any particular 
instrument reflects an assumption about the policy problem and projects a typical consequence. Mandates establish rules, which, in turn, dictate consistent behavior. Responsive action is expected regardless of capacity and, without the rule, would not occur with the desired frequency or consistency. Standards, as a policy tool, establish performance targets and are designed to standardize output and improve system delivery regardless of capacity. Capacity building instruments offer some type of investment cash, tax incentive, or exemption from other policies - to enhance the technical skills and competence of an organization. Ideas, as a policy tool, persuade people that more desirable actions and outcomes exist by rethinking what is essential and visioning a new pattern of behavior within the system (Weiss, 1990). Inducements solicit compliance with offers of money or other valued goods. System-changing instruments assume altering the authority in a faulty organizational structure will improve its efficiency.

Each policy tool has an inherent accountability system. The system establishes who is accountable for what, to whom they are accountable, as well as the process through which they will be held accountable. Mandates, for example, direct changes within an organization but the people implementing those changes are generally accountable to someone outside the organization through an externally-driven process. The external accountability system associated with standards assumes performance scales offer valid and reliable measures of appropriate components of the system. Inducements, on the other hand, particularly those unfunded or insufficient to stimulate change, rely on an internal accountability system. Internal accountability systems make any external monitoring of the expected outcome difficult. Table 1 details these six policy tools. 
Table 1. The Primary Elements in Six Policy Instruments

\begin{tabular}{|c|c|c|c|}
\hline Instrument & $\begin{array}{c}\text { Expected Results/ } \\
\text { Accountability System }\end{array}$ & Costs/Benefits & Assumptions/Consequences \\
\hline $\begin{array}{l}\text { Mandates } \\
\text { Primary } \\
\text { Element: } \\
\text { Rules }\end{array}$ & $\begin{array}{l}\text { Expected Results: } \\
\text { Compliance; Changed } \\
\text { behavior; Creates } \\
\text { Uniformity } \\
\text { External Accountability }\end{array}$ & $\begin{array}{l}\text { Costs: Initiators are responsible for enforcement; } \\
\text { Targets must decide compliance and avoidance } \\
\text { Benefits: Specific benefits to individuals; Diffuse benefits } \\
\text { to society }\end{array}$ & $\begin{array}{l}\text { Assumptions: Action is required regardless of capacity; Good } \\
\text { in its own right; Rule forces action } \\
\text { Consequences: Coercion is required; Policy contains } \\
\text { compliance information; Goal is uniformity may not occur; } \\
\text { Establishes minimum standards; Creates adversarial relationship }\end{array}$ \\
\hline $\begin{array}{l}\text { Standards } \\
\text { Primary } \\
\text { Element: } \\
\text { Performance } \\
\text { Benchmarks } \\
\text { and Targets }\end{array}$ & $\begin{array}{l}\text { Expected Results: } \\
\text { Improved performance or } \\
\text { outputs in targeted area(s) } \\
\text { External Accountability }\end{array}$ & $\begin{array}{l}\text { Costs: Establishes a hierarchy of authority. Initiators } \\
\text { responsible for aligning system of delivery and establishing } \\
\text { (a) scale of performance, (b) oversight, and (c) the } \\
\text { associated accountability mechanism. Producers must } \\
\text { perform regardless of capacity. } \\
\text { Benefits: Standardizes output; improves system delivery. } \\
\text { Establishes a basis for measurement. Defines specific, } \\
\text { observable, performance threshold(s), requirement(s), or } \\
\text { expectation(s). Actors know expectations }\end{array}$ & $\begin{array}{l}\text { Assumptions: Capacity exists or is easily attainable. } \\
\text { Performance scales are valid and reliable. Standards target } \\
\text { appropriate aspects of system performance. } \\
\text { Consequences: Capacity may require investment. Incomplete } \\
\text { understanding of the system may result in misdirected standards } \\
\text { of performance. Variable interpretations of a standard lead to } \\
\text { diffuse and unintended results. }\end{array}$ \\
\hline $\begin{array}{l}\text { Capacity } \\
\text { Building } \\
\text { Primary } \\
\text { Element: } \\
\text { Money/ } \\
\text { Investments }\end{array}$ & $\begin{array}{l}\text { Expected Results: } \\
\text { Enhancement of skill, } \\
\text { competence; long-term } \\
\text { returns } \\
\text { External Accountability }\end{array}$ & $\begin{array}{l}\text { Costs: Short-term costs in initiating government } \\
\text { Benefits: Short-term, specific benefits to receiving agency; } \\
\text { Long-term diffuse benefits to society }\end{array}$ & $\begin{array}{l}\text { Assumptions: Knowledge, skill, competence required; Capacity } \\
\text { is good in its own right or instrumental to other purposes; } \\
\text { Fundamental failure of institution as previously existed } \\
\text { Consequences: Capacity does not exist: Investment needed to } \\
\text { mobilize; Tangible present benefits serve as proxies for future, } \\
\text { intangible benefits }\end{array}$ \\
\hline $\begin{array}{l}\text { Ideas } \\
\text { Primary } \\
\text { Element: } \\
\text { Cogent } \\
\text { Argument }\end{array}$ & $\begin{array}{l}\text { Expected Results: } \\
\text { Persuading people more } \\
\text { desirable means exist } \\
\text { External Accountability }\end{array}$ & $\begin{array}{l}\text { Costs: None } \\
\text { Benefits: Policy can direct patterns of action/inaction; } \\
\text { Empowers }\end{array}$ & $\begin{array}{l}\text { Assumptions: Exert leverage on people; Behavioral repertoires } \\
\text { not fixed } \\
\text { Consequences: No visible sanctions }\end{array}$ \\
\hline $\begin{array}{l}\text { Inducements } \\
\text { Primary } \\
\text { Element: } \\
\text { Money/ } \\
\text { Procurement }\end{array}$ & $\begin{array}{l}\text { Expected Results: } \\
\text { Production of value; } \\
\text { short-term returns } \\
\text { Internal Accountability }\end{array}$ & $\begin{array}{l}\text { Costs: Initiators are responsible for production, oversight, } \\
\text { displacement; Producers are responsible for overhead, } \\
\text { matching, and avoidance } \\
\text { Benefits: Imitators/Producers; Increased budget authority; } \\
\text { Clients-value received }\end{array}$ & $\begin{array}{l}\text { Assumptions: Valued good would not be result without } \\
\text { additional funds; Capacity varies but exists; Funds elicits } \\
\text { performance } \\
\text { Consequences: Funds needed to mobilize action; Range of } \\
\text { action is tolerated }\end{array}$ \\
\hline $\begin{array}{l}\text { System } \\
\text { Changing } \\
\text { Primary } \\
\text { Element: } \\
\text { Authority }\end{array}$ & $\begin{array}{l}\text { Expected Results: } \\
\text { Changed delivery system: } \\
\text { incentives } \\
\text { Newly-created Internal } \\
\text { Accountability }\end{array}$ & $\begin{array}{l}\text { Costs: Loss of authority by established deliveries } \\
\text { Benefits: Gain in authority by new deliverers }\end{array}$ & $\begin{array}{l}\text { Assumptions: Existing institutions and incentives cannot } \\
\text { produce desired results; Changing distribution of authority } \\
\text { changes what is produced } \\
\text { Consequences: Institutional factors incite action: provokes } \\
\text { defensive response; New institution raises new issues }\end{array}$ \\
\hline
\end{tabular}

Source: Adapted from Bales, 2006

\section{The Theory of Tipping Points}

The Tipping Point, as a theory, is used to explain the rapid change in behaviors or outcomes from an otherwise innocuous event. Gladwell (2000) suggests the term "tipping point" is an event with three distinguishing characteristics. The first characteristic is that an action becomes "contagious" and causes an "epidemic" (p. 9). The second characteristic is that "little changes can somehow have big effects" (p. 10). The third, and perhaps most central, is that both changes "happen at one dramatic moment" (p. 8). Like an epidemic, the tipping point is that "dramatic moment... when everything can change all at once" (p.8).

I suggest this theory can be used to describe how nationally-initiated teacher education policy-making became "contagious" and in a very short period of time, teachers, teacher educators, and other school-based personnel were engulfed by an epidemic of standards-based reforms. In fact, Levin (1998) referred to the confluence of these education reforms as a "policy epidemic" (p. 138). In teacher education, these reforms, collectively, all project 
the same theory of action - that regulating the system is necessary to "ensure the improvement of student performance through the improvement of teachers via the improvement of teacher education" (Bates, 2004, p. 119).

Creating a timeline of teacher education policymaking from 1990 to the present allows us to use these theoretical tools to explore the restructuring of teacher education in the United States.

\section{Changes in U.S. Teacher Education Policy 1992-Present}

\section{Teacher Education Policy Changes: 1992 - 2000}

National authorities have used the funding streams and amendments attached to various legislative acts to induce, boost, and force specific state teacher education reforms in a systematic quest to raise student achievement levels. This was done through the legislated alignment of amendments to the Higher Education Act (HEA) in 1992, the Goals 2000: Educate America Act in 1994, and reauthorization of the Elementary and Secondary Education Act in 1994.

Reauthorization of the HEA in 1992 altered direction of the Title II Teacher Quality Enhancement Grant program and provided states with funds for the "recruitment, preparation, licensing, and support of teachers" (United States Department of Education, 2001). In exchange, the grant required both the state and its teacher-preparing institutions to systematically assess the quality of its candidates using a standardized unit of measure. At that time, teacher-preparing institutions reported program completer pass rates in each state, which were then submitted to the U.S. Department of Education as part of the required Title II Report. National authorities compiled the scores, rank ordered program quality, and reported the results publicly.

The 1992 reauthorization also included funding to the Interstate Teacher Assessment and Support Consortium (InTASC) and the National Board for Professional Teaching Standards. The new InTASC standards outlined the knowledge, skills, and dispositions needed by beginning teachers and "were compatible with the more advanced teaching standards developed by the National Board" (Darling-Hammond \& McLaughlin, 1999, p. 387). The group also recommended teacher candidates create a portfolio of evidence to demonstrate their ability to meet each of the standards. The primary constituency for each group was state education agencies responsible for teacher licensing, program approval, and professional development (Council of Chief State School Officers, n.d.-a).

In 1994, the Goals 2000: Educate America Act positioned "teacher education pre-service and professional development as elements of [public] school reform" (Earley \& Schneider, 1996, p. 318). As an inducement policy, it provided funds for states to develop content standards for student learning. It also provided funds to improve pre- and in-service teachers' familiarity with each state's student content standards and the professional development needed 
to support public school children's acquisition of that knowledge. DarlingHammond (1990) summarized the underlying belief system in the Educate America Act:

If policymakers want to change teaching, they must pay attention to teacher knowledge. And if they are to attend to teacher knowledge, they must look beyond curriculum policies to those policies that control teacher education and certification, as well as ongoing professional development, supervision, and evaluation (p. 346).

The Goals 2000 funding streams, however, were insufficient. As a result, states failed to initiate the desired policies.

In 1994, reauthorization of the Elementary and Secondary Education Act (ESEA) mandated states to use a combination of mandates and inducements to force the Goals 2000 standards-based reforms across the fifty states. In doing so, it directed attention to improving the educational quality of what students learn, how teachers teach, and how teachers learn to teach (National Commission on Teaching \& America's Future, 1996). Although there was some variation, most states policies included some or all of the following standards-based reforms:

- academic learning standards for students;

- alignment of teacher standards and various assessments of teacher learning;

- use of student achievement data to monitor performance; and

- accountability provisions that rewarded or sanctioned schools or students on the basis of measured performance (Hamilton, Stecher, \& Yuan, 2008).

Legislators' use of these mandates and inducements also shifted the teacher education accountability system. Now, state approved teacher preparing institutions were accountable to the United States Department of Education through a mandated HEA reporting system and various ESEA funding streams. This decade ushered in the beginning of national efforts to control of teacher education policy-making.

\section{Teacher Education Policy Changes: 2001 - 2008}

The 2001 reauthorization of the ESEA, commonly known as No Child Left Behind (NCLB), tied state compliance of the Goals 2000 policy changes to a series of public reporting systems and essential public and higher education funding. NCLB also put forward the expectation that every child would have access to an Highly Qualified Teacher (HQT). According to national authorities, HQT "must have: 1) a bachelor's degree, 2) full state certification 
or licensure, and 3) prove that they know each subject that they teach" (U. S. Department of Education, 2004, p. 2). In response, 48 states established performance-based teacher standards and mandated the desired changes in teacher knowledge through their authority to approve preparation programs and license teachers.

Each state was also required to:

- set standards for grade-level achievement;

- develop a system to measure the progress of all students and ubgroups of students in meeting those state determined gradelevel standards; and

- establish a definition of "adequate yearly progress" (AYP) to use each year to determine the achievement of each school district and school (p. 22).

Using these criteria, entire Districts and individual Schools could be Identified for Improvement (DIFI and SIFI, respectfully). If a school failed to make AYP for two consecutive years, parents could opt to move their child to a higher performing school, thus transferring the school's Title I money to another school.

States were to hold schools accountable by making annual school report card data publically available. (e.g., NYSED.GOV, 2014 or State of Wisconsin Department of Public Instruction, 2014). Wisconsin implemented standardsbased teacher education program approval and license policies similar to those in other states in 2004 (see Wisconsin Department of Public Instruction, 2001, 34.15.1 and 34.15.2). Theoretically then, teacher preparing programs moving through the approval process should reflect that end.

\section{Teacher Education Policy Changes: 2009 - present}

The latest national effort to tackle the persistent achievement gap, demands for college-ready learners, and our educational standing among other countries was put forward in the 2009 American Recovery and Reinvestment Act (ARRA). ARRA was advanced during the global economic downturn and Washington's gridlocked legislators could not or would not reauthorize the Elementary and Secondary Education Act (ESEA). The ARRA provision of $\$ 4.35$ billion for the Race to the Top Fund lay "the foundation for education reform by supporting investments in innovative strategies that are most likely to lead to improved results for students, long-term gains in school and school system capacity, and increased productivity and effectiveness" (U. S. Department of Education, 2009, p. 2). States awarded Race to the Top (RTT) funds had to establish projects that advanced teaching and learning in four areas:

- adopting rigorous standards and assessments that prepare students for success in college and the workplace; 
- recruiting, developing, retaining, and rewarding effective teachers and principals;

- building data systems that measure student success and inform teachers and principals how they can improve their practices; and

- turning around the lowest-performing schools (p.2).

The first component of the RTT capacity building goal - adopting rigorous standards and assessments that prepare students for success in college and the workplace - has been understood by states as adoption of the Common Core State Standards (CCSS) and utilization of the associated assessments produced by the SMARTER Balanced Assessment Consortium. The SMARTER Balanced Assessment Consortium:

is a group of states funded by the Department of Education to build an online, balanced assessment system based on the CCSS. The goal of SBAC is to develop assessments (summative, benchmark, and formative) that provide meaningful data that educators can use to make sure students graduate from high school ready for college and careers. (Smarter Balanced Assessment Consortium, n.d.)

A second key component of RTT is recruiting, developing, retaining, and rewarding effective teachers and principals. For educator-preparing institutions, this means offering high-quality pathways for aspiring teachers and principals. It also means being able to:

link student achievement and student growth data to the students' teachers and principals, to link this information to the in-State programs where those teachers and principals were prepared for credentialing, and to publicly report the data for each credentialing program in the State. (U. S. Department of Education, 2009, p. 9-10)

In states that received funds, local school district personnel were required to have clear measures of student growth. These data were needed for two reasons. The first, was to mark and chart student learning. The second was because states and districts had to "design and implement rigorous, transparent, and fair evaluation systems for teachers and principals that differentiate[d] effectiveness using multiple rating categories that take into account data on student growth... as a significant factor" (p. 9). These evaluations were to be conducted annually and offer constructive feedback for educator growth. These evaluation systems are also used to inform compensation, promotion, and other personnel-related decisions.

The third RTT component addresses the development of state data systems to inform the continuous improvement of "policy, instruction, operations, management, resource allocation, and overall effectiveness" (U. S. Department of Education, 2009, p. 8). Such data systems also allow national authorities to 
monitor and track student learning progress across the states. The last component of the RTT program directs attention to turning around the lowest performing schools. This component allows states receiving ARRA funds to develop systems for identifying and intervening in the lowest achieving schools. Such interventions can "involve a turnaround model, restart model, school closure, or transformation model" (p. 10).

RTT is a capacity building policy and some would argue it is also systemchanging. This is because it is expected to bring about long-term returns and potentially change the delivery of how teaching and learning take place in the nation's schools. As with other capacity building policies, there are short-term benefits to the receiving agency and potential long term benefits to the society. The success of capacity building policies, however, rests on two assumptions. The first assumption is that the organization - in this case, the state and its local schools - have the knowledge, skill, and competence required to bring about the needed change. The second, and most important, is that developing capacity in the existing system will improve student learning levels.

To date, 20 states and the District of Columbia have received funds across the two application periods. Other states, like Wisconsin, started implanting the expected reforms without funding in exchange for a waiver from the NCLB Adequate Yearly Progress requirements.

\section{Findings and Interpretations}

\section{Tipping Control of U.S. Teacher Education to National Authorities}

Our review of teacher education policies from 1992 to the present illustrates the contagious nature of performance-based standards in teaching and learning. In just 22 years, policy changes have significantly altered the teacher education landscape in the United States. Between 1992 and 1994, three national policies targeted teacher education - Reauthorization of the Higher Education Act in 1992, the Goals 2000 Educate America Act, and the 1994 Reauthorization of the Elementary and Secondary Education (ESEA). One might say this flurry of policy activities reached epidemic proportions. Regardless, teacher education in the United States was resistant.

A closer look at each piece of legislation in this time period reveals that national policy makers relied primarily on inducements to bring about the targeted changes. Yet inducements rest on three underlying assumptions. The first is that funds will elicit performance. The second assumption is that capacity exists but varies among the targeted groups. The third assumption is that the valued good would not result without additional funds. Furthermore, primary responsibility for action and oversight lies on the initiator.

Seven years later, in 2001, national authorities reauthorized the ESEA again and ushered in the mandates of No Child Left Behind. Mandates establish minimum standards and assume action will occur regardless of capacity. They also assume the directive is, in and of itself, right and that rules force action. 
Mandates also require the initiator to supply enforcement and the targeted body must decide between compliance and avoidance. In this manner, mandates require coercion and create adversarial relationships. Compliance brings benefits to individuals but any benefits to society are diffuse. For these reasons $N C L B$ had a destabilizing effect on many educators in public schools, particularly those in urban centers with large numbers of poor and historically underserved children.

Then, in the middle of an economic downturn, the American Recovery and Reinvestment Act (ARRA) used Race to the Top (RTT) funds to build capacity building for the standards-based reform effort. Suddenly, everything "happened at one dramatic moment" (Gladwell, 2000, p. 8). No other policy lever restructured teacher education so drastically. At no other time in history had teacher education undergone so many changes. RTT was the tipping point. States lost their authority over teacher education policymaking because they had not produced the desired changes in teaching and learning.

Today, teacher-preparing institutions are accountable to the United States Department of Education for having performance-based programs tied to student content standards through a mandated Higher Education Act reporting system, various ESEA requirements, and the RTT funding stream. Each policy change involved a different tool. Each policy intensified what students are expected to learn, the tools by which it is measured, and the standards of success. Similarly, the new policies directed attention to how teachers are prepared, what they are expected to know, the tools by which their practice is evaluated, and the standards of "effectiveness". Each policy also shifted the accountability system - who was accountable to whom, what they were accountable for, and through what process - away from local actors. Reviewed over the last 25 years, these changes in policy illustrate how control of teacher education in individual states, like Wisconsin, tipped to national authorities.

\section{Conclusions and Implications}

Finding the tipping point in the policy epidemic to restructure teacher education in the United States illustrates how national efforts have changed from inducements to mandates and the stakes attached to non-compliance increased. As noted earlier, these policy changes occurred because student achievement levels across the 50 states remains low and large gaps exist between majority and minority student population subgroups. Moreover, because these students are the least likely to have fully prepared or licensed teachers (United States Department of Education, 2013), there is an assumption that preparation programs are not adequately training teachers who can address students' achievement needs.

Three conclusions emerge from this review of policy history. Each has implications for future teacher education research, including its role in supporting high levels of student learning and contributing to future policy 
making. Each conclusion also presents an opportunity to formulate an international teacher education knowledge- and research-base.

First, this historical review of teacher education policies in the United States reveals that teacher educators and researchers have not been initiators of these reforms. In fact, there has been a fundamental shift in the locus of control and accountability over the last 25 years. As Elmore and McLaughlin (1988) observed, "the use of policy as an implement of reform grows out of a fundamental distrust of professional judgment. But the dilemma that accompanies this use of policy is that the fate of reforms ultimately depends on those who are the object of distrust" (p. 34). This is important because current standards-based policies have a theory of action that fails to account for the variations in school context we know contribute to student learning inequities. An international exploration of teacher education policies that have successfully reduced achievement gaps across student population subgroups might yield new ideas for the United States and other countries with similar needs.

The second conclusion extends from the first in that there is a need to address the quality of teachers' instruction. As DeMonte (2013) suggests, there is a "lack of clarity and shared knowledge about what systems and activities improve teaching. This is the right time to take stock of what is known; what kinds of activities are currently underway; and what will be needed going forward" (p. 3). Taking stock of instructional quality will require a critical examination of who becomes a teacher and the policy variations dictating how they are prepared and develop a professional practice. We must draw together international, teacher education research that examines policies across the learning to teacher professional sequence, including recruitment, preparation program inputs and outcomes, credentialing and licensing, professional development, evaluation, and relicensing. Engaging in this work, first in each country, and then as a global collective, should yield robust studies in each area. The findings from this work should reveal structural and policy ideas to better address inequities in students' opportunities to learn across nations.

Third, teacher educators around the world should collaboratively engage in research that examines global teacher education reform efforts. Few collaborations of this magnitude exist yet globalization efforts are evident (see for example., UNESCO Strategy on Teachers 2012-2015 and the World Bank Group's Learning for All: Investing in People's Knowledge and Skills to Promote Development). As Levin (1998) pointed out almost two decades ago, "we cannot afford the unthinking copying from elsewhere of education policies dimly understood. Nor can we afford a situation in which many jurisdictions are doing similar things while failing to learn from each other" (p. 139). It is time to learn from each other, pool our research, and advance a policy agenda to improve students' opportunities to learn in every country.

Finally, throughout this narrative, the absence of teacher educators' and teacher education researchers' voices was obvious. To re-center the locus of control in this policy spectacle, teacher education professionals around the globe will need to examine ways to establish a pattern of shared authority with 
policy-makers. This will require better and more effective avenues for communicating teacher education research findings to world leaders and policy-makers.

Taking up these recommendations will help center global teacher education research in future policy reform efforts. These recommendations also establish a framework for improving the learning to teach professional sequence in each country. More importantly, collectively these efforts position teacher educators and teacher education researchers as stewards of student learning around the globe.

\section{Acknowledgements}

I wish acknowledge the Japan-US Educational Reform Exchange Symposium leadership for encouraging the development of this research.

\section{References}

Achieve Incorporated. (n.d.). Next Generation Science Standards. Retrieved from http://bit.ly/1tC192W.

American Association of Colleges for Teacher Education, \& Stanford Center for Assessment, Learning \& Equity (n.d.). About edTPA - Overview. Retrieved from http://bit.ly/1V1U0R0.

Argyris, C., \& Schon, D. A. (1974). Theory in practice: Increasing professional effectiveness. San Francisco: Jossey-Bass, Inc.

Bales, B. (2006). Teacher education policies in the United States: The accountability shift since 1980. Teaching and Teacher Education, 22(May), 395-407.

Bales, B., \& Mueller, J. (2008). Building bridges in the learning to teach professional sequence. The New Educator, 4(2), 152-168.

Bates, R. (2004). Regulation and autonomy in teacher education: Government, community or democracy? Journal of Education for Teaching, 30(2), 117-130.

Borrowman, M. L. (Ed.) (1965). Teacher education in America. New York: Teachers College Press.

Cochran-Smith, M., \& Fries, K. (2008). Research on teacher education: Changing times, changing paradigms. In M. Cochran-Smith, S. Feiman-Nemser, \& D. J. McIntyre (Eds.), Handbook of research on teacher education (3rd ed., pp. 10501093). New York: Routledge.

Common Core State Standards Initiative (2015). Common core state standards initiative-about the standards. Retrieved from http://bit.ly/1sgNl87.

Council of Chief State School Officers (2013). InTASC Model Core Teaching Standards and Learning Progressions for Teachers 1.0. Retrieved from http://bit.ly/1OGZosW.

Council of Chief State School Officers. (n.d.-a). The interstate teacher assessment and support consortium (InTASC). Retrieved from http://bit.ly/1fMe080.

Council of Chief State School Officers. (n.d.-b). Social studies assessment, curriculum, and instruction (SSACI) Retrieved from http://bit.ly/1OGZvoz. 
Datnow, A., \& Park, V. (2009). Conceptualizing policy implementation: Large-scale reform in an era of complexity. In G. Sykes, B. Schneider, \& D. Plank (Eds.), Handbook of education policy research (pp. 348-361). New York: Routledge.

Darling-Hammond, L. (1990). Instructional policy into practice: The power of the bottom over the top. Education Evaluation and Policy Analysis, 12(3), 339-347.

Darling-Hammond, L., \& McLaughlin, M. (1999). Investing in teaching as a learning profession. In L. Darling-Hammond \& G. Sykes (Eds.), Teaching as the learning profession: Handbook of policy and practice. San Francisco: Jossey-Bass.

DeMonte, J. (2013). High-quality professional development for teachers. Retrieved from http://ampr.gs/1QSimwa.

Earley, P. M., \& Schneider, E. J. (1996). Federal policy and teacher education. In J. Sikula (Ed.), Handbook of research on teacher education (2nd ed., pp. 306-320). New York: Macmillan.

Edelman, M. (1988). Constructing the political spectacle. Chicago: University of Chicago Press.

Education Testing Service (n.d.). Praxis ${ }^{\circledR}$ Subject Assessments Overview. Retrieved from http://bit.ly/1KtoUwz.

Elmore, R. F., \& McLaughlin, M. W. (1988). Steady work: Policy, practice and the reform of American education (NIE-400-79-0023). Washington, D.C.: Rand Corporation.

Fuhrman, S. (Ed.). (2001). From the capitol to the classroom: Standards-based reform in the states. Chicago: The University of Chicago Press.

Gladwell, M. (2000). The tipping point. New York: Little, Brown and Company.

Hamilton, L., Stecher, B., \& Yuan, K. (2008). Standards-based reform in the United States: History, research, and future directions. Center on Education Policy and Rand Corporation.

Levin, B. (1998). An epidemic of education policy:(what) can we learn from each other? Comparative education, 34(2), 131-141.

Majone, G. (1989). Evidence, argument, and persuasion in the policy process. New Haven: Yale University Press.

McDonnell, L. M., \& Elmore, R. F. (1987). Getting the job done: alternative policy instruments. Educational Evaluation and Policy Analysis, 9(2), 133-152.

National Commission on Teaching \& America's Future (1996). What matters most: Teaching for America's future. New York: Author.

National Evaluation Series-Wisconsin Foundations of Reading. (2014). What is the Foundations of Reading test?. Retrieved from http://bit.ly/1KYrbWe.

NYSED.GOV. (2014). New York State Report Cards. Retrieved from http://bit.ly/1Omfk4L.

Partnership for Assessment of Readiness for College and Careers (PARCC). (2015). Partnership for Assessment of Readiness for College and Careers: About. Retrieved from http://bit.ly/1MjdwX7. 